\title{
Peertechz
}

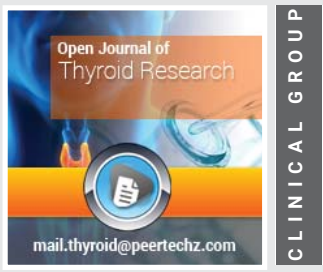

\section{Thyroid and its functionalities on human body}

\section{Moid Munawar*}

Received: 02 December, 2020

Accepted: 05 December, 2020

Published: 06 December, 2020

*Corresponding author: Moid Munawar, Shadan College, Osmania Unisivertiy, Telengana, India, E-mail:moidmunawar7@gmail.com

https://www.peertechz.com

Shadan College, Osmania Unisivertiy, Telengana, India

Thyroid chemicals is a piece of hypothalamic-pituitarythyroid. The Hypothalamus discharge a low plasma convergence of thyroid chemical and produces Thyrotropin-Releasing Hormone (TRH) into the hypophysis framework.

TRH ties receptors present on thyrotrophic cells of the foremost pituitary organ make it to deliver Thyroid Stimulating Hormone (TSH) in the fundamental course. TSH ties to TSH receptors on the basolateral film of thyroid follicular cells and driving the union and arrival of thyroid chemical.

The thyroid normally the like butterfly shape that stays on the low front of the neck, along the front of the windpipe. The thyroid has two side projections, associated by isthmus in the center. At the point when the thyroid is in typical size, you can't have the option to feel it. Nerves for voice quality likewise go through the thyroid.

T3 is a second thyroid chemical that is delivered by the thyroid organ, yet additionally different tissues through enzymatic change of T4. T3 keeps up muscle control, mind capacity and advancement, heart and stomach related capacities. It assumes a part in the body's metabolic rate and the control of the bone wellbeing.

Thyroxine (T4) is delivered by the thyroid organ under the guideline of the nerve center and pituitary organ. The circle signs to the nerve center in arrival of thyrotropin-delivering chemical, which at that point courses the pituitary organ to create the thyroid invigorating chemical.

The thyroid's chemicals control primary body capacities, containing: Heart rate, breathing, muscle strength, feminine cycles, focal sensory systems, body weight, cholesterol levels and internal heat level.

Metabolic cycles expanded by thyroid chemicals are as per the following: Thermogenesis, basal metabolic, protein amalgamation, Glycogenosis, Gluconeogenesis and Lipogenesis.
Check for updates
On the huge scope the pituitary-thyroid with contribution from the nerve center concerning your body's prerequisites, decides how much thyroid chemical your thyroid organ discharges.

$>$ The free coursing thyroid chemicals are available in your tissues are cradled on a moment to-minute framework, by TBG and the other thyroid-restricting blood proteins.

o The real T3 to T3 atomic receptors at the site of a cell's DNA saw to be directed by a few intracellular proteins. This guarantees that a lot of thyroid chemical is contained to your tissues consistently, and yet it permit the very fine control for the thyroid-DNA interface inside single cells.

o Removed of the thyroid organ: The thyroid have been precisely eliminated or artificially crushed.

o Exposure of the over the top measure of iodide: Cold and sinus meds, the heart medication amiodarone, certain differentiation colors given before the $\mathrm{X}$-beams may uncover you much iodine.

o You might be at high danger for creating hypothyroidism in the event that, on the off chance that you had thyroid issues before.

o Lithium: This medication have additionally been introduced as a reason for hypothyroidism.

The chemicals produces are fundamentally imperative to human turn of events and to a sound life. The troublesome idea of thyroid capacity is the improvement in complex instruments that the nature had set up for the guideline of thyroid chemicals.

Having a lot of $\mathrm{T} 3$ in the circulation system is alluded to the thyrotoxicosis. This condition results from over action in the thyroid organ, or hyperthyroidism. Hyperthyroidism presents in conditions, for example, Graves illness, irritation 
of the thyroid or a benevolent tumor. Most indications of thyrotoxicosis incorporate weight reduction, expanded craving, palpitations, unpredictable period, sluggishness, touchiness, and hair diminishing. Hyperthyroidism can likewise happen when supplements with $\mathrm{T} 3$ are engrossing it.
Hypothyroidism is a condition that happens if the thyroid organ doesn't delivers enough thyroid chemical. This is because of immune system conditions, for example, Hashimoto's thyroiditis or meds. Hypothyroidism can likewise happen in pituitary brokenness, for example, pituitary tumors or aggravation.

\section{Discover a bigger Impact and Visibility of your article publication with}

\section{Peertechz Publications}

\section{Highlights}

- Signatory publisher of ORCID

* Signatory Publisher of DORA (San Francisco Declaration on Research Assessment)

* Articles archived in worlds' renowned service providers such as Portico, CNKI, AGRIS, TDNet, Base (Bielefeld University Library), CrossRef, Scilit, J-Gate etc.

* Journals indexed in ICMJE, SHERPA/ROMEO, Google Scholar etc.

* OAI-PMH (Open Archives Initiative Protocol for Metadata Harvesting)

* Dedicated Editorial Board for every journal

- Accurate and rapid peer-review process

* Increased citations of published articles through promotions

* Reduced timeline for article publication

Submit your articles and experience a new surge in publication services (https://www.peertechz.com/submission).

Peertechz journals wishes everlasting success in your every endeavours. 